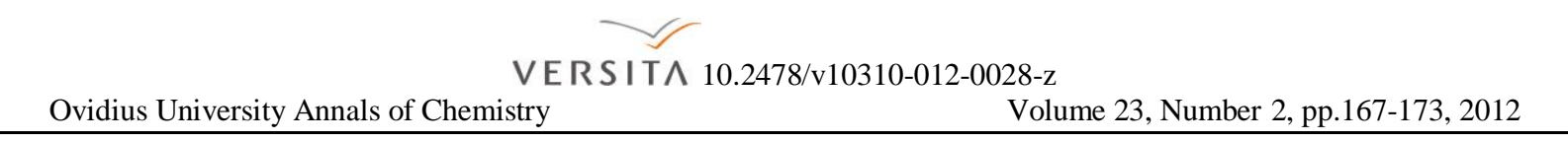

\title{
Trace elements balance in a refinery
}

Claudia Irina KONCSAG* and Anca Iuliana DUMITRU

Ovidius University of Constanta, Department of Chemistry and Chemical Engineering, 124 Mamaia Blvd, 900527 Constanta, Romania

\begin{abstract}
The trace elements balance is performed whenever the refinery processes a new type of oil. The goal of the balance is to find the distribution of the trace elements in the products and residues for the market. Also, the balance can warn about the accumulation of metals in the catalysts, this affecting their activity in time. This work presents the case study of a refinery processing a light and sulphurous oil with a medium concentration of trace elements. The study highlighted the following: the highest levels of concentration in feed and products are for $\mathrm{Na}$ and $\mathrm{Si}$; in general, trace elements concentrate in heavier factions and residues and especially in the coke as a product or as deposited on calaysts; following the balance, heavy metals concentrate in the coke deposit on FCC catalyst in range of $53 \%$ for $\mathrm{V}$ to $83 \%$ for As; heavy metals concentrate in the gasoline hydrotreating catalyst in range of $7 \%$ for $\mathrm{Ni}$ to $87 \%$ for $\mathrm{V}$.
\end{abstract}

Keywords: crude oil, trace elements balance, ICP-MS

\section{Introduction}

About half of the elements from the periodic table were found in the crude oil: carbon and hydrogen dominate, sulphur, oxygen and nitrogen are in percents and metals in trace, $\mathrm{mg} / \mathrm{kg}$ or $\mu \mathrm{g} / \mathrm{kg}$. A large variety of trace elements was reported in different sources but the most complete list [1] include 28 of them. The most frequent is $\mathrm{Na}$, then $\mathrm{Si}$ but among the transitional metals, $\mathrm{Ni}$ and $\mathrm{V}$ are more abondant. The study of the metals in crude oil gives clues about the origin and age [2,3]. Also, the study of metals content in crude oil and their distribution in refinery products performed whenever the refinery processes a new type of oil, would give information about the processability of the oil and the value of the products on the market. Moreover, the metal balance in an oil refinery when the quality of feed changes will provide data about accumulation in catalysts with impact on their deactivation, this allowing to preview the length of processing cycle.

The present work is an example of trace elements balance in the refinery in order to conclude on the processability of that oil.

\section{Experimental}

The refinery processes a light $\left(d_{15}^{15}=0.8512\right)$ and sulphurous $(1.05 \% \mathrm{wt})$ oil. The balance is performed in a typical processing day, using mass balance of feed and products and trace elements concentration in each of them.

The main trace elements in the oil have been monitored: $\mathrm{V}, \mathrm{Ni}, \mathrm{Zn}, \mathrm{As}, \mathrm{Na}$ and $\mathrm{Si}$. Their concentration has been analysed by a spectrometric method. Due to expected low concentration of some metals, the ICP-MS method was prefered. It was used a Agilent 7500ce aparatus. Detection limits were: $0.01130 \mu \mathrm{g} / \mathrm{L}$ for $\mathrm{V}, 0.07522 \mu \mathrm{g} / \mathrm{L}$ for $\mathrm{Ni}$, $0.09363 \mu \mathrm{g} / \mathrm{L}$ for $\mathrm{Zn}, 0.02369 \mu \mathrm{g} / \mathrm{L}$ for As, 0.2887 $\mu \mathrm{g} / \mathrm{L}$ for $\mathrm{Na}$ and $0.2389 \mu \mathrm{g} / \mathrm{L}$ for $\mathrm{Si}$.

The standard methods used for sample preparation were ASTM D-5184/1995 [4], ASTM D 4951/1996 [5] and ASTM D5600/1998 [6] based on acid digestion of the ash in such conditions that the losses of volatile metallic compounds were minimized. Direct introduction of petroleum product in plasma, dilluted or not, was avoided due to the matrix effect.

Material balance on each process for every metal was performed with Eq.1, using the raw flows 
[kg/day], product yields $(\%)$ and metal content $[\mathrm{mg} / \mathrm{kg}]$

$($ raw - flow $) \times\left(\right.$ metal $\_$content $)=$

$\sum($ product_flow $) \times($ metal_content $)+$

+ losses

Since losses were under $0.5 \%$ in each process, the mass balance closed satisfactorily for each element. Data obtained with Eq.1 served to calculate the distribution of trace elements in products of the processes and then to observe the tendency of metals to concentrate in one product, or another or on catalysts

\section{Results and Discussions}

The results of metal analysis in raw materials and products of the refinery give information about the content of trace elements in petroleum product and they are shown in Table 1. The concentration are expressed as $\mathrm{mg} / \mathrm{kg}$ (ppm wt)

Table 1. The trace metals concentration in raw materials and products, $\mathrm{mg} / \mathrm{kg}$

\begin{tabular}{|c|c|c|c|c|c|c|c|}
\hline \multicolumn{8}{|c|}{ Atmospheric and Vacuum Distillation of Crude Oil } \\
\hline Raw or product & $\begin{array}{c}\text { Daily } \\
\text { quantity, } t\end{array}$ & As & $\mathbf{V}$ & Si & $\mathrm{Ni}$ & $\mathbf{Z n}$ & $\mathbf{N a}$ \\
\hline Crude oil & 11463 & 0.21 & 2.5 & 0.66 & 1.1 & 1.2 & 12 \\
\hline Light naphtha & 1182 & 0.0046 & 0.0005 & 0.79 & 0.01 & 0.024 & 0.66 \\
\hline Heavy naphtha & 1001 & 0.038 & 0.0008 & 0.47 & 0.013 & 0.028 & 0.6 \\
\hline Jet fuel & 1186 & 0.049 & 0.13 & 0.38 & 0.011 & 1.1 & 3.1 \\
\hline Gas oil & 2805 & 0.16 & 0.22 & 0.31 & 0.1 & 1.2 & 12.75 \\
\hline Vacuum distillate & 3096 & 0.22 & 0.66 & 0.56 & 0.12 & 1.5 & 11 \\
\hline Vacuum residue & 2153 & 0.53 & 12. 00 & 1.41 & 5.5 & 2 & 29 \\
\hline \multicolumn{8}{|c|}{ Naphtha Hydrotreating } \\
\hline Heavy naphtha in line & 1170 & 0.0046 & 0.0005 & 0.79 & 0.01 & 0.024 & 0.66 \\
\hline Naphta from tank & 1139 & 0.018 & 0.0006 & 0.44 & 0.013 & 0.028 & 0.6 \\
\hline Coke gasoline & 238 & 0.13 & 0.001 & 1.5 & 0.017 & 0.037 & 1 \\
\hline Mixed Feed & 2547 & 0.022 & 0.0006 & 0.70 & 0.012 & 0.027 & 0.66 \\
\hline Hydrotreated gasoline & 1514 & 0.014 & 0.0001 & 0.37 & 0.013 & 0.02 & 0.52 \\
\hline C5-C6 cut & 605 & 0.0005 & 0.0001 & 0.1 & 0.014 & 0.026 & 0.63 \\
\hline Gas C2-C4 & 428 & N/A & N/A & N/A & N/A & N/A & N/A \\
\hline \multicolumn{8}{|c|}{ Fluid Catalytic Cracking } \\
\hline Hydrotr. vac. distillate & 3712 & 0.21 & 0.61 & 0.52 & 0.011 & 1.01 & 9.8 \\
\hline FCC light gasoline & 1545 & 0.0022 & 0.0006 & 0.063 & 0.02 & 0.033 & 0.57 \\
\hline FCC heavy gasoline & 111 & 0.039 & 0.009 & 0.11 & 0.037 & 0.062 & 3.5 \\
\hline FCC light gas oil & 501 & 0.14 & 1.3 & 0.26 & 0.11 & 1.4 & 8.1 \\
\hline FCC heavy gas oil & 282 & 0.18 & 1.4 & 5.2 & 0.13 & 1.5 & 8.8 \\
\hline Gas+coke on catalyst & 1273 & N/A & N/A & N/A & N/A & N/A & N/A \\
\hline
\end{tabular}




\begin{tabular}{|c|c|c|c|c|c|c|c|}
\hline \multicolumn{8}{|c|}{ Coke Unit } \\
\hline Vacuum residue & 2029 & 0.54 & 12 & 1.41 & 5.5 & 2 & 29 \\
\hline Coke gasoline & 238 & 0.13 & 0.001 & 1.52 & 0.017 & 0.037 & 1 \\
\hline Light coke gas oil & 612 & 0.25 & 1.5 & 0.23 & 0.12 & 1.03 & 5.9 \\
\hline Heavy coke gas oil & 596 & 0.19 & 1.2 & 0.54 & 0.089 & 1.3 & 10 \\
\hline Petroleum coke & 583 & 1.43 & 40.53 & 3.43 & 19.26 & 4.8 & 88.1 \\
\hline
\end{tabular}

From Table 1, one can see that, for every process in the refinery, the metal content in products and residuues increases with the boiling temperature of these; in Table 1 products of each process are in range of increasing boiling temperatures. The metals level is higher in feed and products from distillation of crude oil and Fluid Catalytic Cracking (FCC): ppm, and even higher in Coke unit products (dozen of ppm). $\mathrm{Na}$ is the main metal in all petroleum products, $\mathrm{V}, \mathrm{Zn}$ and $\mathrm{Ni}$ are
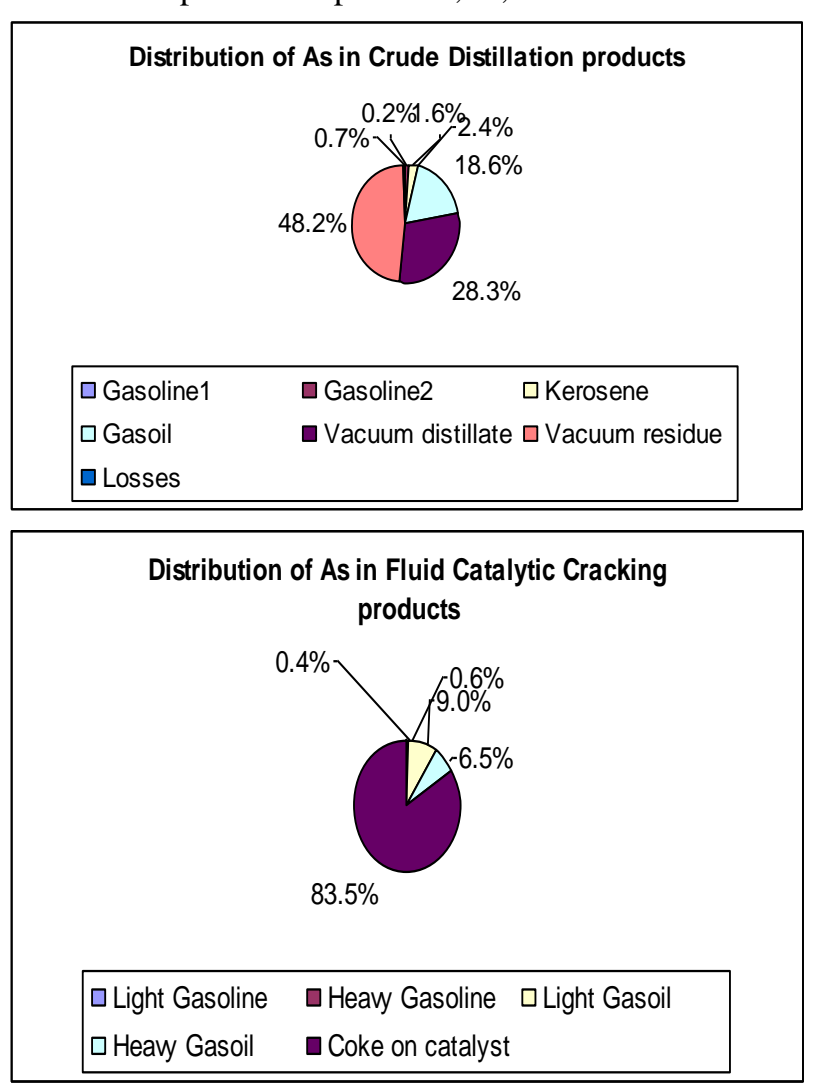

second third and fourth in the raw and products. $\mathrm{Ni}$ and $\mathrm{V}$ concentrate in residues and are also present over $1 \mathrm{ppm}$ in gas oils. Only $\mathrm{Zn}$ is found in FCC gasoline in concentration over $1 \mathrm{ppm}$.

Following the mass balance on each process for every metal (Eq.1), the distribution of metals in the products was calculated.

In Fig. 1, the distribution of As in products of different processes is shown.

Distribution of As in Gasoline Hydrotreating products

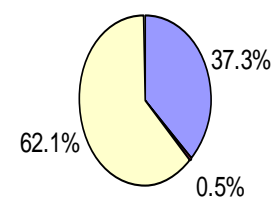

$\square$ Hydrotreated gasoline $\square$ Hydrotreated light cut C5/C6 $\square$ Losses

Distribution of As in Delayed Coke products

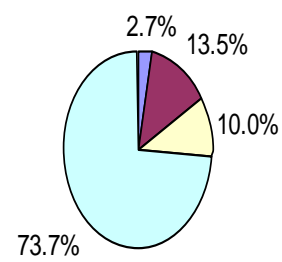

口Gasoline $\square$ Light Gasoil $\square$ Heavy Gasoil $\square$ Petroleum coke

Fig.1. Distribution of As in the refinery products 

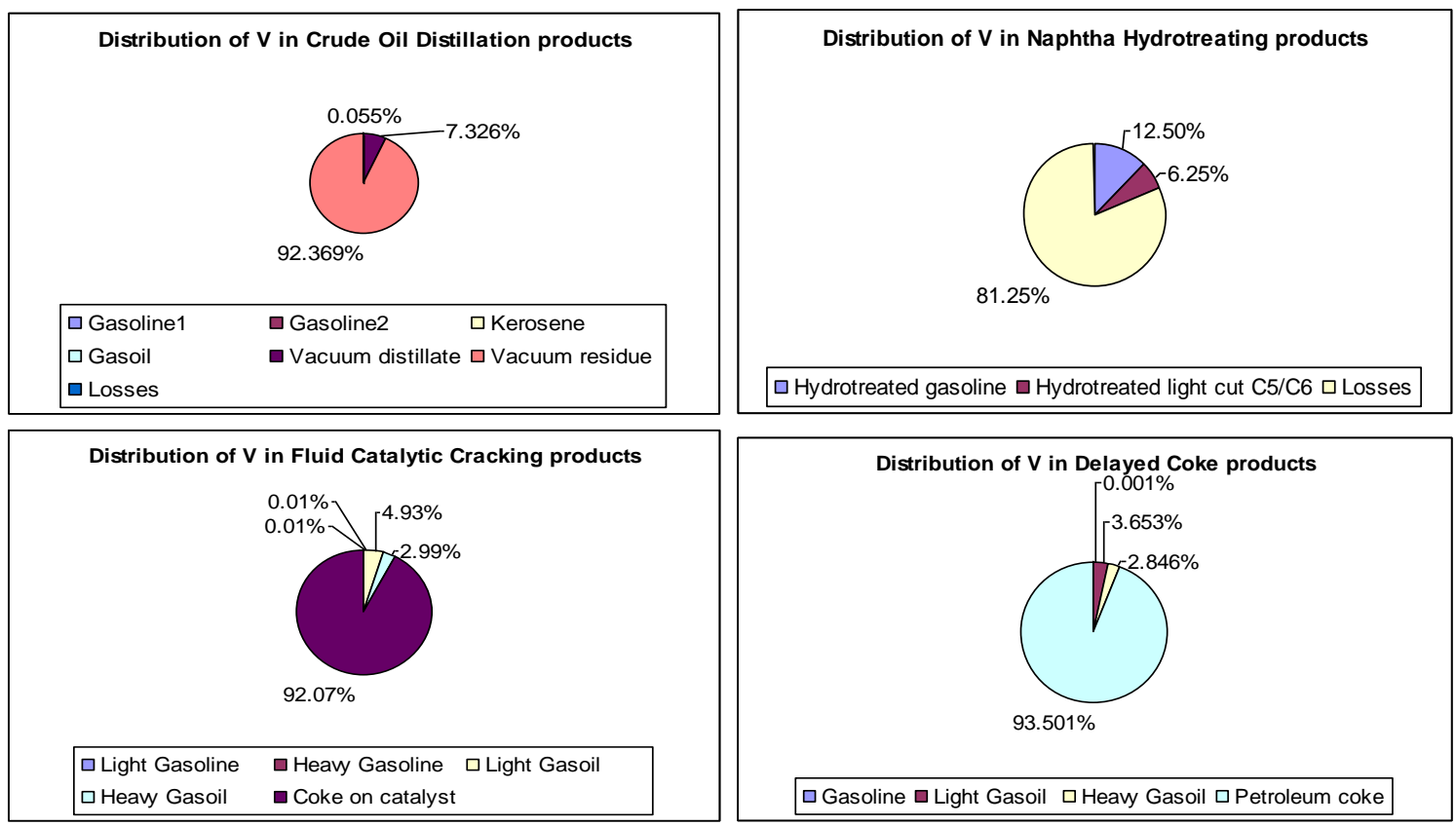

Fig.2. Distribution of $\mathrm{V}$ in the refinery products

As seen, As accumulates in residues $(48.2 \%$ in vacuum residue proceeding from crude oil, $73.7 \%$ in petroleum coke ). A good share concentrates on catalysts: $83.5 \%$ for all the As in the feed of Fluid Catalytic Cracking is found on the catalyst and $62.1 \%$ of that in Naphtha Hydrotreating process is removed from naphtha, but one can't say how much is on catalyst or gone with fuel gas as volatile compounds; the analysis of the metals in hydrotreating catalyst is pointless since the catalyst already contains a high level of metals so small adding due to the feed is not detectable.

As seen in Fig. 2, a similar tendency was noticed for the Vanadium but this one accumulates over $90 \%$ in residues and on FCC catalyst. Accordingly, removal of $\mathrm{V}$ from naphtha during hydrotreating is $81.25 \%$ comparing with $\mathrm{Ni}$ $(62.1 \%)$

In Fig. 3, the distribution of $\mathrm{Ni}$ seems similar to that of As and V, with a significant difference: $\mathrm{Ni}$ is accumulating more in hydrotreated gasoline than previous metals $(64.4 \%$ comparing with 37.3 $\%$ As and $12.5 \% \mathrm{Ni}$ ), this meaning that the share for hydrotreating catalyst plus losses with fuel gas is much smaller $(7.8 \%)$. The conclusion is that removal of $\mathrm{Ni}$ from naphtha during hydrotreating is less effective than for As and V.

In Fig. 4, the distribution of $\mathrm{Zn}$ is shown. $\mathrm{Zn}$ is accumulating in residues and catalyst like $\mathrm{As}, \mathrm{Ni}, \mathrm{V}$ but in smaller measure (e.g. Zn share in vacuum residue is $33.8 \%$ since for As the share is $48.2 \%$, for $\mathrm{V}$ it is $93.4 \%$, and $93.6 \%$ for $\mathrm{Ni}$. Also, $\mathrm{Zn}$ is found in gasolines in very small proportion: 0.1 $0.2 \%$ in all the processes very much alike with the other metals. Differently, the $\mathrm{Zn}$ is distributed rather uniformly in naphtha hydrotreating products, so the removal of $\mathrm{Zn}$ from naphtha is not very effective during the hydrotreating process.

Silicon (Fig. 5) accumulates mostly in residues (petroleum coke and coke on FCC catalyst) but an important share is found in distillated products too $(12.2 \%$ in heavy gasoline from crude oil distillation, $31.4 \%$ in hydrotreated gasoline, $5 \%$ in light gasoline and $76 \%$ in heavy gasoline from FCC); however, this doesn't affect the quality of gasoline pool. 

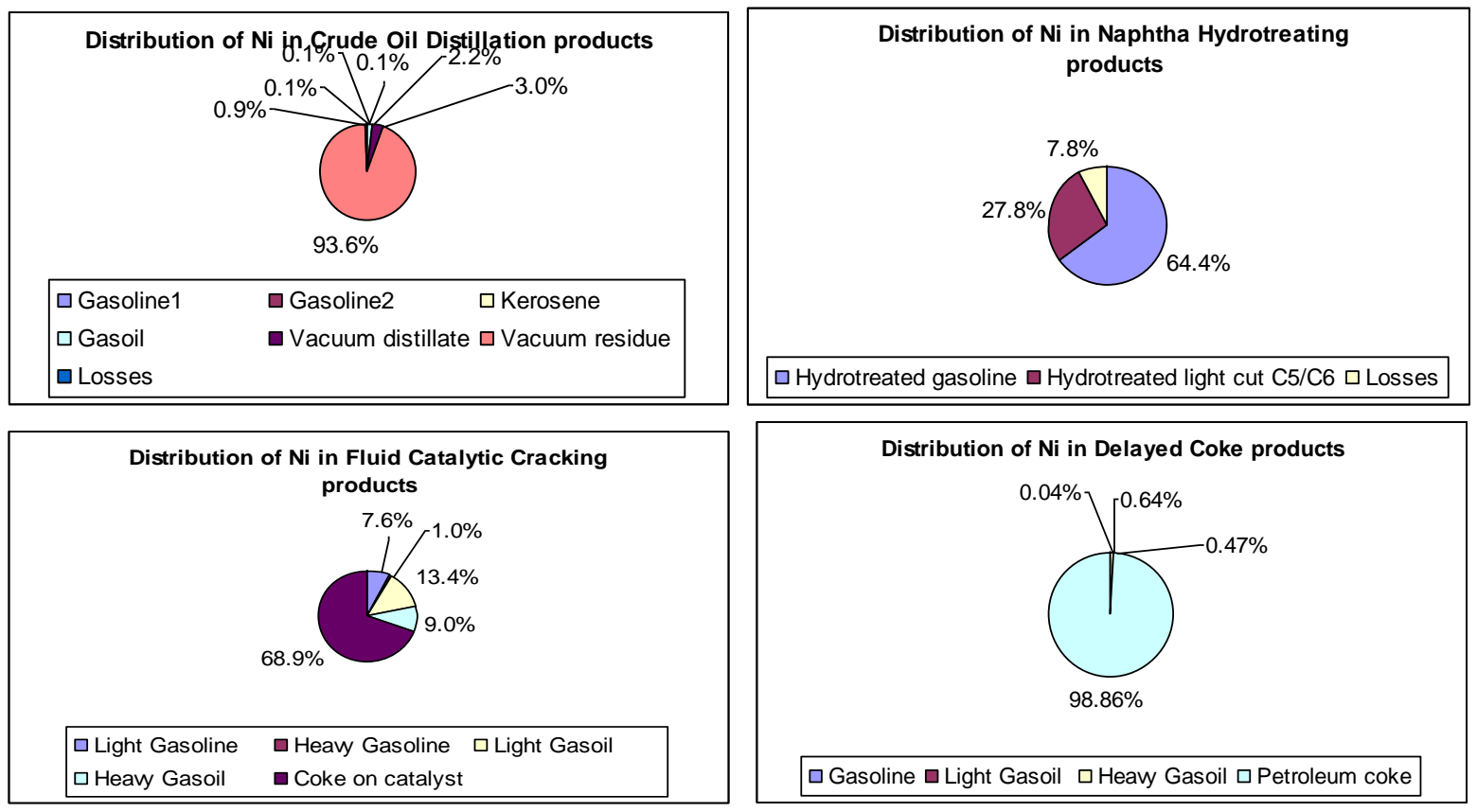

Fig.3. Distribution of Ni in the refinery products
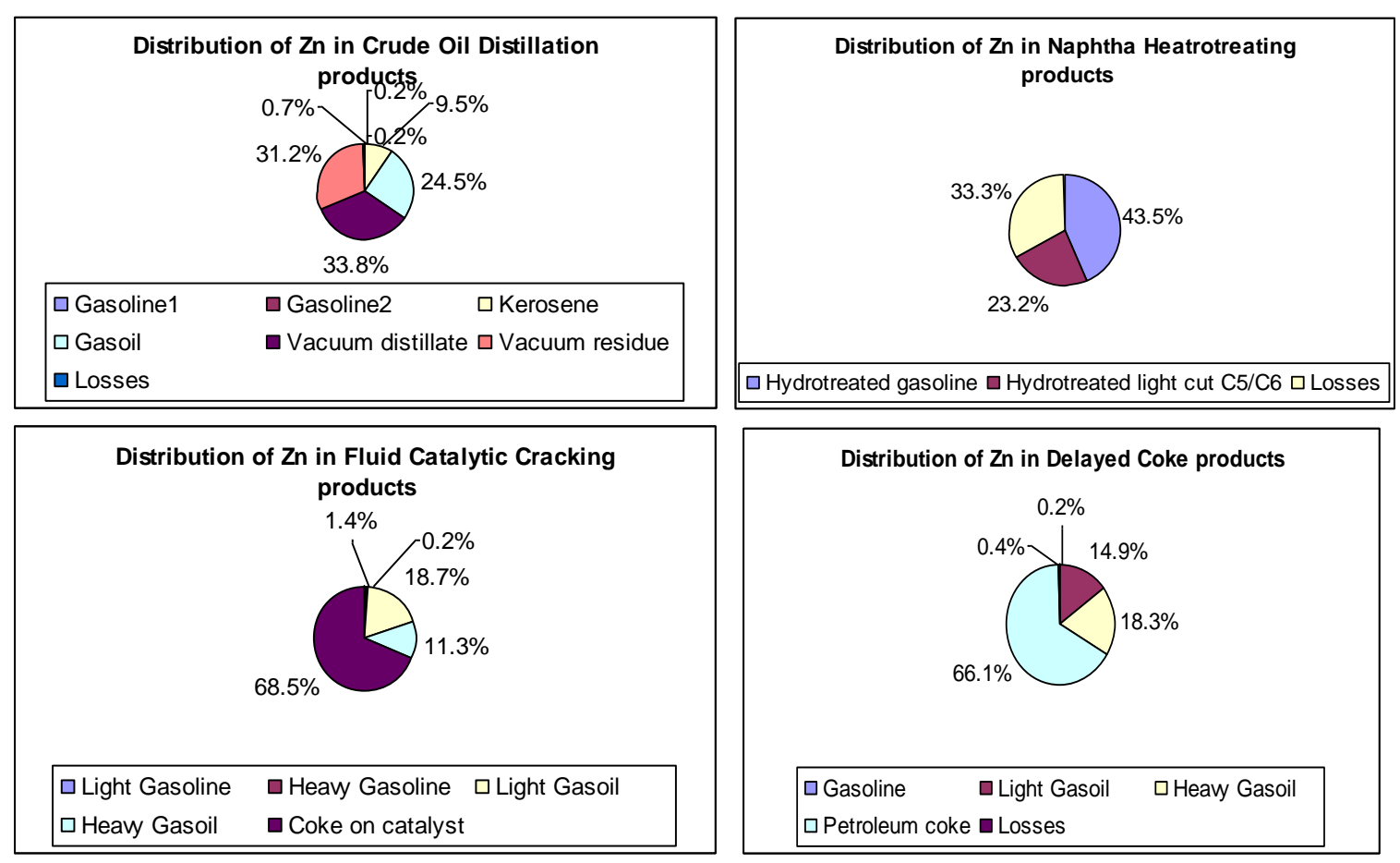

Fig.4. Distribution of $\mathrm{Zn}$ in the refinery products 

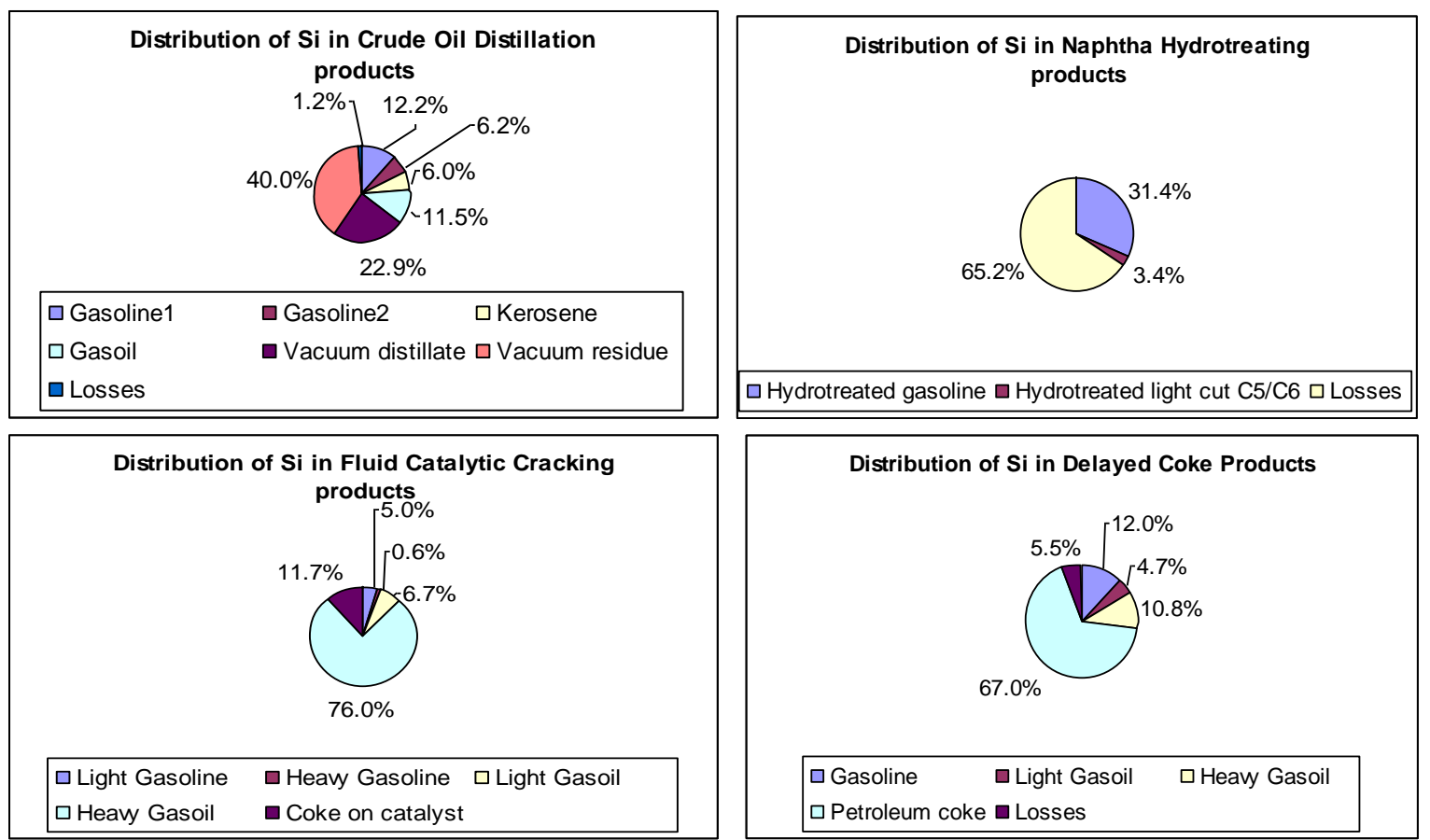

Fig.5. Distribution of Si in the refinery products
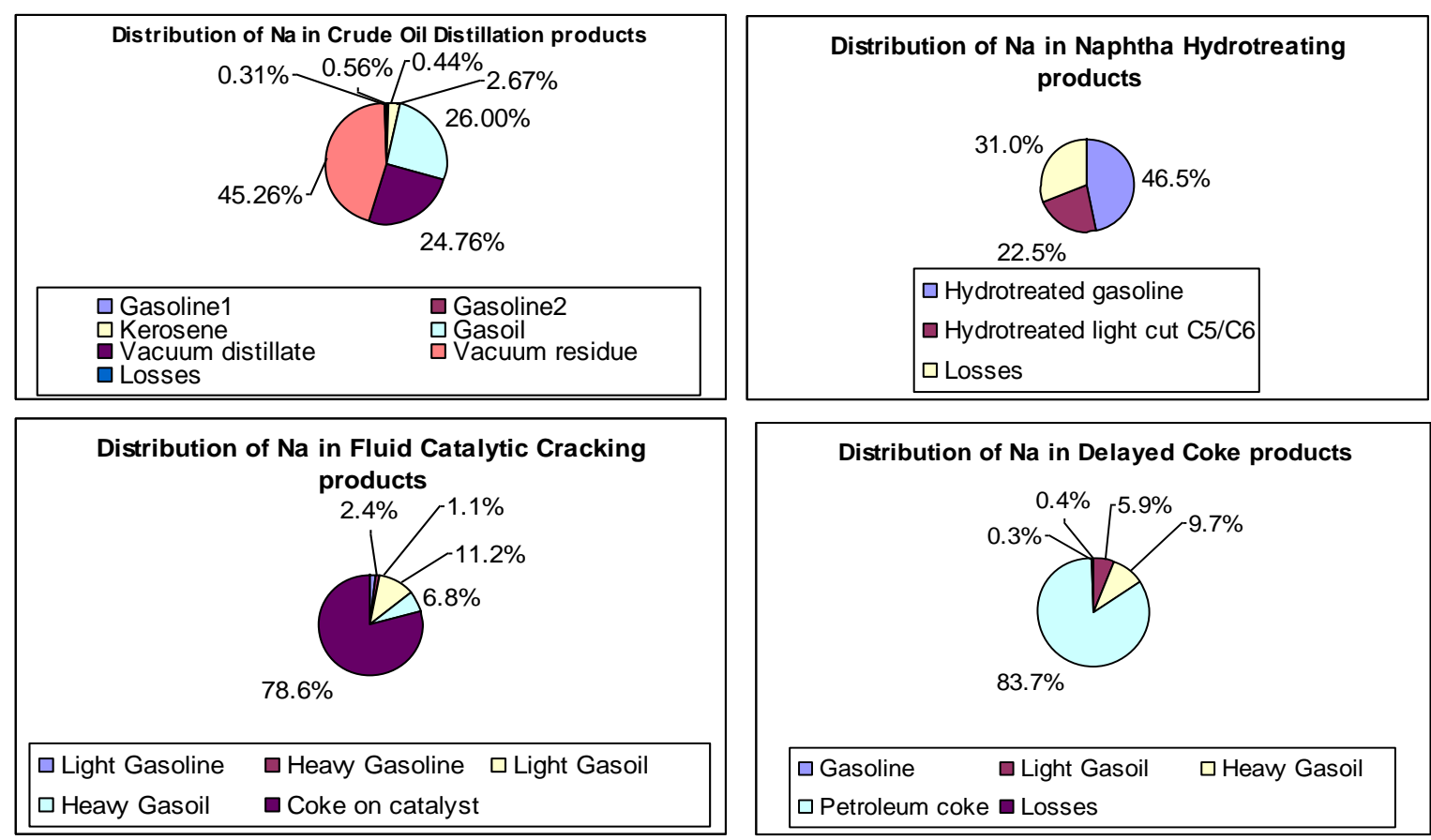

Distribution of $\mathrm{Na}$ in Delayed Coke products

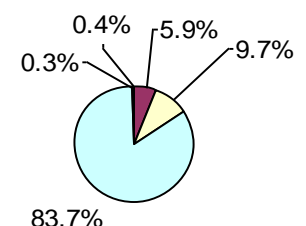

$83.7 \%$

\begin{tabular}{|l}
$\square$ Gasoline $\quad \square$ Light Gasoil $\square$ Heavy Gasoil \\
$\square$ Petroleum coke $\square$ Losses
\end{tabular}

Fig.6. Distribution of $\mathrm{Na}$ in the refinery products 
Natrium (Fig. 6), the most frequent metal in crude oil, is accumulating in residues as all the other trace elements but also in gas oil $(26 \%$ in crude distillation gas oil, $11.2 \%$ in light and $6.8 \%$ in heavy gas oil from FCC and $9.7 \%$ in the gas oil proceeding from Delayed Coke unit). Like Si, it is found also in gasolines in important shares but $\mathrm{Na}$ as $\mathrm{Si}$ are harmless for the gasoline and gasoil quality.

\section{Conclusions}

Mass balance is an useful method for predicting the trace elements level in the products proceeding from a certain crude oil. Also, the metal balance can serve to measure indirectly the quantity lost in emissions and deposed on catalysts.

This study was performed in a refinery processing a light and sulphurous crude oil. The conclusions after the metals balance were the following:

- In Crude Oil Distillation process, all the metals concentrate in vacuum residue but an important share is also in the vacuum distillate; in gasoline, less than $0.1 \%$ of the heavy metals $(\mathrm{As}, \mathrm{Ni}, \mathrm{V})$ concentrate and in kerosene only As represents more de $1 \%$ of the total quantity entered with the crude; due to the high flowrate of gasoline, the level of As in the naptha is in range of $\mathrm{ppb}$;

- In Naphtha Hydrotreating process, As is removed in proportion of $67.3 \%, 85.3 \%$ of $\mathrm{Ni}$ is removed but only $7.4 \%$ of $\mathrm{Ni}$ is removed; the concentration level of heavy metals in hydrotreated gasoline is: $14 \mathrm{ppb}$ for As, $13 \mathrm{ppb}$ for $\mathrm{Ni}$ and $0.1 \mathrm{ppb}$ for $\mathrm{V}$; this level of concentration affects in small measure the activity of the catalyst in the downstream process: Reforming Gasoline;

- In Fluid Catalytic Cracking process, metals accumulate in the coke deposit on the catalyst, except Si concentrating in heavy gas oil (76\%);

- During Delayed Coke process, all metals accumulates in the petroleum coke; in distillates, the concentration level of heavy metals $\mathrm{Ni}, \mathrm{V}$ and As is under $1 \mathrm{ppm}$ and only $\mathrm{V}$ is slightly over $1 \mathrm{ppm}$ in gas oil.

\section{References}

* E-mail address: ckoncsag@yahoo.com

[1] J. Sanbayar, D. Monkhoobor, B. Avid, Advances in Chemical Engineeering and Science 2, 113 (2012)

[2] L. Lopez, S. Lo Monaco, Fuel, 83, 365 (2004)

[3] F. Galarraga, K. Reategui, A. Martinez, M. Martinez, J.F. Llamas, G. Marquez, Journal of Petroleum Science and Engineering, 61, 9 (2008) [4]***ASTM D-5184/1995 "Aluminium and Silicon in Fuel Oils by Ashing, Fusion, ICP-AES and AAS Spectrometry"

[5] ***ASTM D-4951/1996 "Additive Elements in Lubricating Oils by ICP-AES"

[6] ***ASTM D-5600/1998 "Standard Method for Trace Metals in Petroleum Coke by Inductively Coupled Plasma Atomic Emission Spectrometry"

Submitted: October $1^{\text {st }} 2012$ Accepted in revised form: November $15^{\text {th }} 2012$ 